\title{
Total Quality Management and Financial Performance of Construction Companies in Ha Noi
}

\author{
Anh Duy Nguyen ${ }^{1}$, Cuong Hung Pham ${ }^{2} \&$ Long Pham ${ }^{3}$ \\ ${ }^{1}$ Thang Long Construction Quality Consultant Joint Stock Company, Vietnam \\ ${ }^{2}$ Foreign Trade University, Ho Chi Minh City Campus, Vietnam \\ ${ }^{3}$ National Economics University, Vietnam \\ Correspondence: Cuong Hung Pham, Foreign Trade University, Ho Chi Minh City Campus, \#15D5, Ward 25, Binh \\ Thanh District, Ho Chi Minh City, Vietnam.
}

Received: April 11, 2016

Accepted: May 4, 2016

Online Published: May 13, 2016

doi:10.5430/ijfr.v7n3p41

URL: http://dx.doi.org/10.5430/ijfr.v7n3p41

\begin{abstract}
Concerning performance improvement of Hanoi construction companies, a conceptual framework was developed in this study. This framework was used not only to evaluate the practices of TQM, but also to examine the relationship between TQM and organizational performance. The sample of the study includes construction companies in Hanoi. This study evaluated the impact of TQM dimensions on performance. The results of the six regression models (TQM-OP1; TQM-OP2; TQM-OP3; TQM-OP4; TQM-OP5; TQM-OP6) show that there is enough statistical evidence to demonstrate important relationships between TQM and organizational performance.

Organizations who implement the activities of TQM will positively increase their performance. In model TQM-OP1, there are three regression relationships with market and profitability, namely, employee involvement, process management, and supplier relationship. The relationship between market and profitability with supplier relationship is explained that organizations focus on developing long term relationships with suppliers, they gain opportunities in occupying and expanding market. There is one regression relationship with employee involvement in model TQM-OP3. This is employee involvement. In fact, employee involvement impacts on the effort of the employees. When the management emphasizes employee involvement, the employees feel convenient about their job, and they trust the organization. They become actively involved in working and contributing their efforts for the organization. One relationship with process efficiency is shown in model TQM-OP4, namely, process management. In model TQM-OP5, the only one significant relationship with process effectiveness is supplier relationship. The relationship of supplier relationship with process effectiveness can be explained that focusing on long term relationships with suppliers will result in process effectiveness. By the same token, for model TQM-OP6, the only one significant relationship with order time is supplier relationship. The relationship of supplier relationship with order time can be explained that focusing on long term relationships with suppliers will result in increase in order time.
\end{abstract}

Keywords: Total Quality Management, TQM, financial performance, construction companies, Ha Noi

\section{Introduction}

Vietnam is a developing country and the construction sector is the backbone of its economy. Vietnam is building a lot of constructions. Therefore, it is imperative to evaluate the extent of the implementation of quality management initiatives in the construction companies of Vietnam, especially construction companies in Hanoi - capital of Vietnam to see whether these initiatives have improved business results or not. Another shortcoming in the existing TQM literature is that the majority of existing empirical studies have been conducted in the context of industries like chemical production, heavy machinery, automobile production, electrical and electronics. There are not many comprehensive empirical studies available from the context of construction companies. Thus, empirical studies on TQM need to be replicated in the context of this sector. The main aim of this study is to investigate the implementation of TQM practices in Hanoi construction companies. To achieve this aim, the study was conducted in the construction industry, the very important sector in Vietnam. This will be first study on Vietnam's construction sector which will provide empirical evidence about the implementation of TQM. Furthermore, this study will provide empirical evidence about the association between the certification of the latest version of quality management system 
and organizational performance and implementation of TQM practices. This relationship has not yet been investigated adequately in the existing literature.

\section{Literature Review}

$T Q M$ is not a cut-and-dried reality but an amorphous philosophy that is continuously enacted by managers, consultants, and researchers who make choices based not only on their understanding of principles of TQM but also on their own conceptual frameworks concerning the nature of organizations. (1994, p.448)

A review of the research indicates that the literature seems to agree on the scope of this management approach. Initially, both academics and practitioners considered it to be an approach used for the improvement of every process in an organization. For example, Juran \& Godfrey (1999) indicate that "TQM has become an umbrella term for many different collections of concepts, methods, and tools". Gryna et al. (2007) also support this view.

The traditional scope of quality activities is undergoing a radical and exciting change from the historical emphasis on quality of physical products in manufacturing industries ( little ' $Q$ ') to what is now emerging as the application of quality concepts to all products, all functional activities, and all industries (big ' $Q$ ').

Table 1 shows changes in the understanding of quality within organizations while moving from little 'Q' to big 'Q'.

Evans \& Lindsay (2008) support Gryna et al. (2007) describing the concept of TQM as extending from the "quality of management" to the "management of quality". They consider that "rather than a narrow engineering or production- based technical discipline, quality took on a new role that permeated every aspect of running an organization".

Table 1. The relationship between TQM practices and organizational performance

\begin{tabular}{|c|c|c|c|c|}
\hline Study & Country & $\begin{array}{l}\text { Nature of } \\
\text { organizations }\end{array}$ & Research method & Findings \\
\hline $\begin{array}{l}\text { Corredor } \\
\text { and Goni } \\
(2010)\end{array}$ & Spain & $\begin{array}{l}\text { Manufacturing } \\
\text { and services }\end{array}$ & $\begin{array}{lr}\text { Analysis of secondary } \\
\text { data related to the firm's } \\
\text { profitability } r \\
\text { achievement of quality } \\
\text { awards. }\end{array}$ & $\begin{array}{l}\text { Earlier adopters of quality awards } \\
\text { can get more benefit as compare } \\
\text { to late adopters. There was no } \\
\text { significant difference in the } \\
\text { performance of TQM and } \\
\text { non-TQM firms. }\end{array}$ \\
\hline $\begin{array}{l}\text { Bou-Lluso } \\
\mathrm{r} \text { et al. } \\
(2009)\end{array}$ & Spain & $\begin{array}{l}\text { Manufacturing } \\
\text { and services }\end{array}$ & $\begin{array}{lr}\text { Questionnaire } & \text { survey. } \\
\text { Respondents: } & \text { CEOs \& } \\
\text { quality } & \text { managers. } \\
\text { Analysis } & \text { Technique: } \\
\text { SEM } & \end{array}$ & $\begin{array}{l}\text { The excellence of enablers has a } \\
\text { strong positive effect on results } \\
\text { excellence. Both MBNQA and } \\
\text { EFQM Excellence Model are the } \\
\text { best models of TQM. }\end{array}$ \\
\hline $\begin{array}{l}\text { Macinati } \\
(2008)\end{array}$ & Italy & $\begin{array}{l}\text { Health } \\
\text { providers }\end{array}$ & $\begin{array}{lr}\text { Questionnaire } & \text { survey. } \\
\text { Respondents: } & \text { Managing } \\
\text { Director. } & \text { Analysis } \\
\text { Technique: } & \text { Factor } \\
\text { analysis, Correlations }\end{array}$ & $\begin{array}{l}\text { There is no significant } \\
\text { relationship between financial } \\
\text { results and quality management } \\
\text { practices. However, quality } \\
\text { management practices are } \\
\text { positively associated with } \\
\text { subjective performance. }\end{array}$ \\
\hline $\begin{array}{l}\mathrm{Su} \text { et al } \\
(2008)\end{array}$ & China & $\begin{array}{l}\text { Manufacturing } \\
\text { and services }\end{array}$ & $\begin{array}{l}\text { Questionnaire survey \& } \\
\text { interviews. Respondents: } \\
\text { Quality managers, } \\
\text { Analysis Technique: } \\
\text { SEM }\end{array}$ & $\begin{array}{l}\text { Quality management practices } \\
\text { have an indirect effect on } \\
\text { business performance rather than } \\
\text { a direct effect. However, this } \\
\text { effect is mediated by quality and } \\
\text { research and development } \\
\text { construct. }\end{array}$ \\
\hline $\begin{array}{l}\text { Tari, } \\
\text { Molina } \\
\text { and }\end{array}$ & Spain & $\begin{array}{l}\text { Manufacturing } \\
\text { and services }\end{array}$ & $\begin{array}{lr}\text { Questionnaire } & \text { survey. } \\
\text { Respondents: } & \text { Managers, } \\
\text { Analysis } & \text { Technique: }\end{array}$ & $\begin{array}{l}\text { TQM practices have direct and } \\
\text { indirect effect on organizational } \\
\text { performance. }\end{array}$ \\
\hline
\end{tabular}




\begin{tabular}{|c|c|c|c|c|}
\hline $\begin{array}{l}\text { Castejon } \\
(2007)\end{array}$ & & & SEM & \\
\hline $\begin{array}{l}\text { Feng et al. } \\
(2006)\end{array}$ & $\begin{array}{l}\text { Australia } \\
\text { and } \\
\text { Singapore }\end{array}$ & $\begin{array}{l}\text { Manufacturing } \\
\text { and services }\end{array}$ & $\begin{array}{lr}\text { Questionnaire } & \text { survey, } \\
\text { Respondents: } & \text { Senior } \\
\text { Managers, } & \text { Analysis } \\
\text { Technique: SEM } & \end{array}$ & $\begin{array}{l}\text { TQM dimensions like leadership } \\
\text { \& people management are more } \\
\text { related to innovation, whereas } \\
\text { customer satisfaction \& process } \\
\text { management are more related to } \\
\text { quality performance. }\end{array}$ \\
\hline $\begin{array}{l}\text { Demirbag } \\
\text { et al } \\
(2006)\end{array}$ & Turkey & Textile SMEs & $\begin{array}{lr}\text { Questionnaire } & \text { survey. } \\
\text { Respondents: } & \\
\text { Senior/quality } & \text { managers. } \\
\text { Exploratory } & \& \\
\text { Confirmatory } & \text { Factor } \\
\text { Analysis } & \end{array}$ & $\begin{array}{l}\text { There is a strong positive } \\
\text { association between TQM } \\
\text { practices and non-financial } \\
\text { performance. However, TQM } \\
\text { practices have a weak direct } \\
\text { relationship with financial } \\
\text { performance. }\end{array}$ \\
\hline $\begin{array}{l}\text { Sila and } \\
\text { Ebrahimp } \\
\text { ur (2005) }\end{array}$ & USA & Manufacturing & $\begin{array}{l}\text { Questionnaire survey. } \\
\text { Respondents: } \\
\text { Senior/quality managers. } \\
\text { Analysis Technique: } \\
\text { SEM }\end{array}$ & $\begin{array}{l}\text { Among different constructs of } \\
\text { TQM, only leadership and } \\
\text { process management have a direct } \\
\text { positive relationship with } \\
\text { business results. }\end{array}$ \\
\hline $\begin{array}{l}\text { Rahman } \\
\text { and } \\
\text { Bullock } \\
(2005)\end{array}$ & Australia & Manufacturing & $\begin{array}{lr}\text { Questionnaire } & \text { survey. } \\
\text { Respondents: } & \text { Managers. } \\
\text { Analysis Technique: } & \text { Trisis, } \\
\text { Factor } & \text { analysis, } \\
\text { correlations \& regression } \\
\text { analysis }\end{array}$ & $\begin{array}{l}\text { The hard and soft elements of } \\
\text { TQM are positively associated } \\
\text { with each other. However, hard } \\
\text { elements have a direct effect on } \\
\text { organizational performance, } \\
\text { whereas soft elements of TQM } \\
\text { can affect performance indirectly, } \\
\text { through hard TQM elements. }\end{array}$ \\
\hline $\begin{array}{l}\text { Kaynak } \\
(2003)\end{array}$ & USA & $\begin{array}{l}\text { Manu } \\
\text { and } s\end{array}$ & $\begin{array}{lr}\text { Questionnaire } & \text { survey. } \\
\text { Respondents: } & \text { Senior } \\
\text { managers. } & \text { Analysis } \\
\text { Technique: SEM } & \\
\end{array}$ & $\begin{array}{l}\text { TQM practices have a positive } \\
\text { direct and indirect on al } \\
\text { performance. }\end{array}$ \\
\hline $\begin{array}{l}\text { Prajogo } \\
\text { and Sohal } \\
(2003)\end{array}$ & Australia & $\begin{array}{l}\text { Manufacturing } \\
\text { and services }\end{array}$ & $\begin{array}{l}\text { Questionnaire survey. } \\
\text { Respondents: Managers. } \\
\text { Analysis Technique: } \\
\text { SEM }\end{array}$ & $\begin{array}{l}\text { TQM practices are positively and } \\
\text { significantly related to product } \\
\text { quality and innovation. }\end{array}$ \\
\hline $\begin{array}{l}\text { Douglas } \\
\text { and Judge } \\
(2001)\end{array}$ & USA & Hospitals & $\begin{array}{l}\text { Questionnaire survey and } \\
\text { secondary data, } \\
\text { Respondents: } \\
\text { CEO/Director quality. } \\
\text { Analysis Technique: } \\
\text { Correlation \& } \\
\text { Regression Analysis }\end{array}$ & $\begin{array}{l}\text { TQM practices are positively and } \\
\text { significantly associated with } \\
\text { financial performance } \\
\text { industry and } \\
\text { performance. }\end{array}$ \\
\hline $\begin{array}{l}\text { Ahire and } \\
\text { Drey fus } \\
(2000)\end{array}$ & USA & Manufacturing & $\begin{array}{l}\text { Questionnaire } r \text { survey. } \\
\text { Respondents: mid-level } \\
\text { managers. Analysis } \\
\text { Technique: Confirmatory } \\
\text { Factor Analysis, Path } \\
\text { Analysis }\end{array}$ & $\begin{array}{l}\text { The design and process } \\
\text { management efforts have an equal } \\
\text { effect on internal and external } \\
\text { product quality }\end{array}$ \\
\hline
\end{tabular}

\section{Research Method}

In order to examine the relationship between TQM and organizational performance, the following hypotheses are developed below. 
Although TQM has been widely regarded as a tool for improving quality and performance such as profit and market share, the success rate is not high (Harari, 1997). To understand the success of TQM, many studies have been conducted to investigate the impact of TQM on performance. However, most researches have used data collected from developed countries. It is not clear whether it applies to less developed or developing countries as well, particularly Vietnam. The purpose of this study is to understand how the organizational performance of Hanoi's construction companies is related to the dimensions of TQM.

H1: There are positive relationships between "TQM dimensions" and "market and profitability"

$\mathrm{H} 2$ : There are positive relationships between "TQM dimensions" and "customer satisfaction"

H3: There are positive relationships between "TQM dimensions" and "employee satisfaction"

H4: There are positive relationships between "TQM dimensions" and "process efficiency"

H5: There are positive relationships between "TQM dimensions" and "process effectiveness"

H6: There are positive relationships between "TQM dimensions" and "order time"

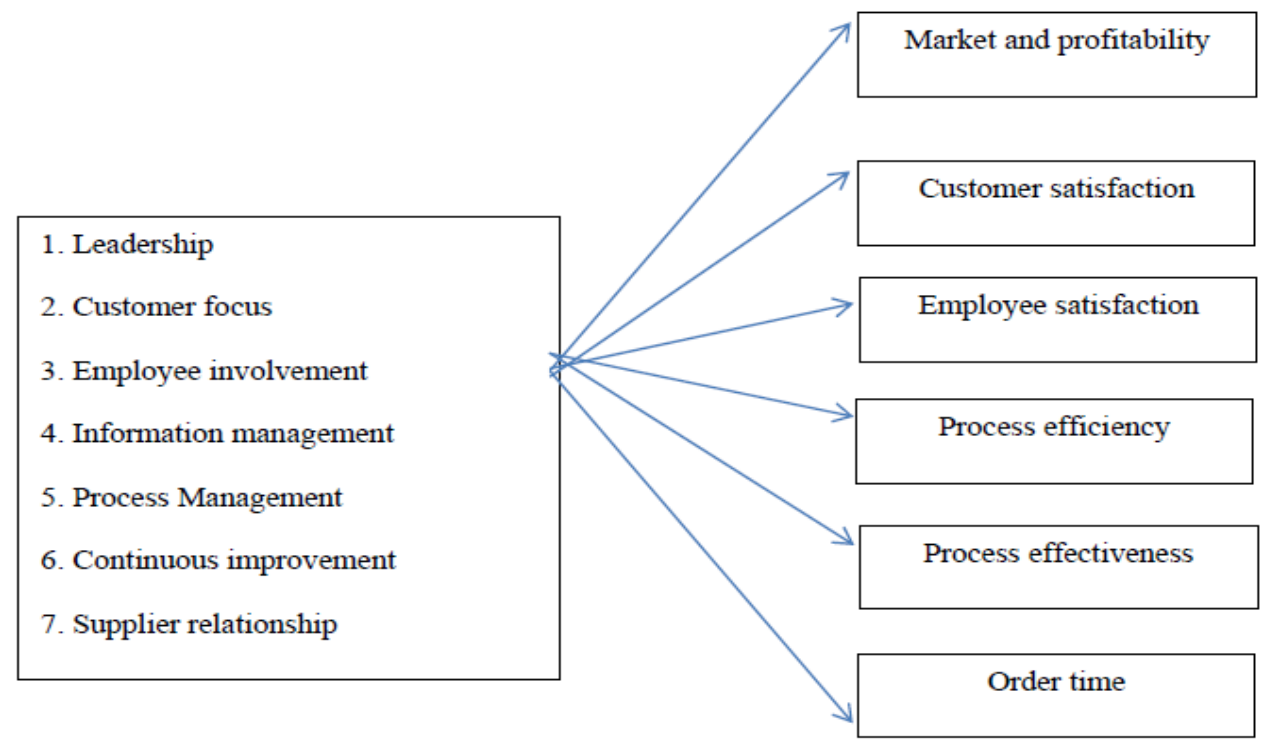

Figure 1. Research model

In order to achieve the objectives of the study, within the wider analysis mentioned in the conceptual framework in this section, the population for this study is construction companies in Hanoi. There were about 400 construction companies in Hanoi which have obtained certificates of quality, mostly ISO9000 certificates (over 95\%). Thus the population of this study is 400 . The organizations with quality certificates are labeled as "group 1".

\section{Research Results}

\subsection{Reliability and Validity of the Survey Instrument}

A QMS model with 39 items was developed based on the seven dimensions leadership (TQM 11, TQM12, TQM13, TQM14, TQM15, TQM16, TQM17), customer focus (TQM21, TQM22, TQM23, TQM24, TQM25), employee involvement (TQM31, TQM32, TQM33, TQM34, TQM35, TQM36), information management (TQM41, TQM42, TQM43, TQM44, TQM45, TQM46, TQM47), process management (TQM51, TQM52, TQM53, TQM54, TQM55), continuous improvement (TQM61, TQM62, TQM63, TQM64), and supplier relationship (TQM71, TQM72, TQM73, TQM74, TQM75).

Reliability. Cronbach's alpha is a commonly used measure of reliability of a set of two or more construct indicators. Reliability is a measure of internal consistency of the construct indicator. Alpha values range between 0 and 1.0 with higher values indicating higher reliability among the indicators (Hair et al., 1998). Nunnally (1978) suggested that in exploratory research, alpha value of .60 is sufficient, An internal consistency analysis was performed separated for the items under each of the criteria. The reliability coefficient (Cronbach's alpha) was calculated for each construct and 
ranged between .900 (supplier relationship - S) and .975 (leadership - L). The alpha values found for each construct indicated that each construct was a strongly reliable measure.

\section{Validity}

Content validity. A measure has content validity if there was general agreement from the literature that the TQM model has measurement items that cover all aspects of the variable being measured. Since selection of the initial measurement items was based on the extensive review of international literature and several frameworks of quality management system, e.g. quality management principles of ISO 9000, and the Malcolm Baldrige Quality Award, the measures were generally considered to have content validity. Therefore, the measurement instrument does measure the key dimensions of the QMS models.

Table 4. Results of reliability and validity of quality management factors

\begin{tabular}{|c|c|c|c|c|c|c|c|c|}
\hline Criteria & Constructs & Items & $\begin{array}{l}\text { Factor } \\
\text { loading }\end{array}$ & Community & $\begin{array}{l}\text { Eigen- } \\
\text { values }\end{array}$ & $\begin{array}{l}\% \\
\text { Variance } \\
\text { explained }\end{array}$ & KMO & $\begin{array}{c}\text { Cronbach's } \\
\text { alpha }\end{array}$ \\
\hline \multirow[t]{7}{*}{ Leadership } & \multirow{7}{*}{$\begin{array}{l}\text { Leadership } \\
\text { (L) }\end{array}$} & TQM11 - Create clear and quality vision & .817 & .883 & 17.865 & 16.273 & .933 & .975 \\
\hline & & TQM12 - Consider customer's needs & .864 & .923 & & & & \\
\hline & & TQM13 - Consider supplier's needs & .855 & .911 & & & & \\
\hline & & TQM14 - Consider employee's needs & .846 & .871 & & & & \\
\hline & & TQM15 - Provide freedom to employees to work & .824 & .837 & & & & \\
\hline & & $\begin{array}{l}\text { TQM16 - Provide required resources and training } \\
\text { to employees }\end{array}$ & .826 & .818 & & & & \\
\hline & & $\begin{array}{l}\text { TQM17 - Encourage and recognize employee's } \\
\text { contributions }\end{array}$ & .818 & .698 & & & & \\
\hline \multirow[t]{5}{*}{$\begin{array}{l}\text { Customer } \\
\text { focus }\end{array}$} & \multirow[t]{5}{*}{$\begin{array}{l}\text { Customer } \\
\text { focus }(\mathrm{CF})\end{array}$} & $\begin{array}{l}\text { TQM21 - Research customer's needs and feedback } \\
\text { on products/ services provided }\end{array}$ & .705 & .697 & 4.028 & 32.328 & .933 & .910 \\
\hline & & $\begin{array}{l}\text { TQM22 - Link customer's needs and feedback to } \\
\text { design, production and delivery processes }\end{array}$ & .769 & .752 & & & & \\
\hline & & $\begin{array}{l}\text { TQM23 - Receive and respond to customer's needs } \\
\text { and feedback on products/ services provided } \\
\text { quickly }\end{array}$ & .747 & .853 & & & & \\
\hline & & $\begin{array}{l}\text { TQM24 - Manage customer relationships } \\
\text { systematically }\end{array}$ & .848 & .780 & & & & \\
\hline & & TQM25 - Measuring customer's satisfaction & .802 & .740 & & & & \\
\hline \multirow[t]{6}{*}{$\begin{array}{l}\text { Employee } \\
\text { involvement }\end{array}$} & \multirow{6}{*}{$\begin{array}{l}\text { Employee } \\
\text { involvement } \\
\text { (E) }\end{array}$} & $\begin{array}{l}\text { TQM31 - Employees understand the importance of } \\
\text { their contribution and role in the organization }\end{array}$ & .704 & .805 & 3.297 & 44.391 & .933 & .939 \\
\hline & & $\begin{array}{l}\text { TQM32 - Employees identify constrains to their } \\
\text { performance }\end{array}$ & .744 & .806 & & & & \\
\hline & & $\begin{array}{l}\text { TQM33 - Employees joint working teams/ groups } \\
\text { to improve quality or solve problems }\end{array}$ & .806 & .771 & & & & \\
\hline & & $\begin{array}{l}\text { TQM34 - Employees openly discuss problems and } \\
\text { issue during operations }\end{array}$ & .796 & .807 & & & & \\
\hline & & $\begin{array}{l}\text { TQM35 - Employees willingly share their } \\
\text { knowledge and experience }\end{array}$ & .792 & .805 & & & & \\
\hline & & $\begin{array}{l}\text { TQM36 - Employees actively seek opportunities to } \\
\text { enhance their competence, knowledge and } \\
\text { experience }\end{array}$ & .772 & .805 & & & & \\
\hline
\end{tabular}


Table 4. Results of reliability and validity of quality management factors (cont.)

\begin{tabular}{|c|c|c|c|c|c|c|c|c|}
\hline Criteria & Constructs & Items & $\begin{array}{l}\text { Factor } \\
\text { loading }\end{array}$ & Community & $\begin{array}{l}\text { Eigen- } \\
\text { values }\end{array}$ & $\begin{array}{l}\% \\
\text { Variance } \\
\text { explained }\end{array}$ & KMO & $\begin{array}{c}\text { Cronbach's } \\
\text { alpha }\end{array}$ \\
\hline \multirow[t]{7}{*}{$\begin{array}{l}\text { Information } \\
\text { management }\end{array}$} & $\begin{array}{c}\text { Information } \\
\text { management (I) }\end{array}$ & $\begin{array}{l}\text { TQM41 - Comprehensive set of performance } \\
\text { indicators developed }\end{array}$ & .811 & .815 & 2.244 & 56.098 & .933 & .967 \\
\hline & & $\begin{array}{l}\text { TQM42 - Data and information being sufficiently } \\
\text { accurate and reliable }\end{array}$ & .790 & .888 & & & & \\
\hline & & TQM43 - Data being accessible to those who need it & .890 & .903 & & & & \\
\hline & & $\begin{array}{l}\text { TQM44 - Analysis of data and information using } \\
\text { appropriate and scientific methods }\end{array}$ & .890 & .891 & & & & \\
\hline & & $\begin{array}{l}\text { TQM45 - Decision making and action taking based } \\
\text { on factual analysis }\end{array}$ & .863 & .889 & & & & \\
\hline & & TQM46 - Database maintenance & .853 & .774 & & & & \\
\hline & & $\begin{array}{l}\text { TQM47 - Information sources and their uses within } \\
\text { the organization continuously refined }\end{array}$ & .677 & .870 & & & & \\
\hline \multirow[t]{5}{*}{$\begin{array}{c}\text { Process } \\
\text { management }\end{array}$} & $\begin{array}{c}\text { Process } \\
\text { management }(\mathrm{P})\end{array}$ & $\begin{array}{l}\text { TQM51 - Establishing clear responsibility and } \\
\text { accountability for managing key activities }\end{array}$ & .858 & .847 & 2.086 & 66.330 & .933 & .954 \\
\hline & & $\begin{array}{l}\text { TQM52 - Controlling the quality rand operational } \\
\text { performance of key processes }\end{array}$ & .828 & .912 & & & & \\
\hline & & $\begin{array}{l}\text { TQM53 - Strictly analyzing significant variations in } \\
\text { process and output to make corrections }\end{array}$ & .878 & .846 & & & & \\
\hline & & TQM54 - Measuring the capability of key activities & .789 & .801 & & & & \\
\hline & & $\begin{array}{l}\text { TQM55 - Focusing on resources, method and } \\
\text { material that will improve key activities }\end{array}$ & .780 & .802 & & & & \\
\hline \multirow[t]{4}{*}{$\begin{array}{l}\text { Continuous } \\
\text { improvement }\end{array}$} & $\begin{array}{l}\text { Continuous } \\
\text { improvement } \\
\text { (CI) }\end{array}$ & $\begin{array}{l}\text { TQM61 - Establishing goals for continuous } \\
\text { improvement and measuring the improvement } \\
\text { results }\end{array}$ & .679 & .782 & 1.434 & 75.346 & .933 & .918 \\
\hline & & $\begin{array}{l}\text { TQM62 - Training employees with the methods and } \\
\text { tools for continuous improvement }\end{array}$ & .659 & .802 & & & & \\
\hline & & $\begin{array}{l}\text { TQM63 - Implementing continuous improvement } \\
\text { of products/services, processes, and systems }\end{array}$ & 669 & .814 & & & & \\
\hline & & $\begin{array}{l}\text { TQM64 - Recognizing and informing of } \\
\text { improvements }\end{array}$ & .656 & .687 & & & & \\
\hline \multirow[t]{5}{*}{$\begin{array}{l}\text { Supplier } \\
\text { relationship }\end{array}$} & $\begin{array}{l}\text { Supplier } \\
\text { relationship }(\mathrm{S})\end{array}$ & $\begin{array}{l}\text { TQM71- Emphasizing of identifying and selecting } \\
\text { key suppliers }\end{array}$ & .595 & .671 & 1.030 & 82.012 & .933 & .900 \\
\hline & & $\begin{array}{l}\text { TQM72 - Establishing supplier relationships with } \\
\text { long-term considerations }\end{array}$ & .572 & .848 & & & & \\
\hline & & $\begin{array}{l}\text { TQM73 - Clearly and openly communicating with } \\
\text { suppliers }\end{array}$ & .826 & .852 & & & & \\
\hline & & $\begin{array}{l}\text { TQM74 - Sharing information and future plans with } \\
\text { suppliers }\end{array}$ & .878 & .821 & & & & \\
\hline & & $\begin{array}{l}\text { TQM75 - Establishing joint development and } \\
\text { improvement activities with suppliers }\end{array}$ & .873 & .819 & & & & \\
\hline
\end{tabular}


Table 5. Results of reliability and validity of organizational performance factors

\begin{tabular}{|c|c|c|c|c|c|c|c|}
\hline Constructs & Items & $\begin{array}{l}\text { Factor } \\
\text { loading }\end{array}$ & Community & Eigen-values & $\begin{array}{c}\% \\
\text { Variance } \\
\text { explained } \\
\end{array}$ & KMO & $\begin{array}{l}\text { Cronbach's } \\
\quad \text { alpha }\end{array}$ \\
\hline \multirow{5}{*}{$\begin{array}{l}\text { Market and } \\
\text { profitability }\end{array}$} & Revenue and profits & .856 & .741 & 4.347 & 53.62 & .915 & .898 \\
\hline & Sales & .931 & .784 & & & & \\
\hline & Market share & .946 & .754 & & & & \\
\hline & New market/ new customers & .879 & .799 & & & & \\
\hline & Competitive advantages & .915 & .757 & & & & \\
\hline \multirow{3}{*}{$\begin{array}{c}\text { Customer } \\
\text { satisfactions }\end{array}$} & Long-term relationship with customers & .941 & .815 & 2.158 & 65.73 & .915 & .879 \\
\hline & Customer satisfaction & .979 & .864 & & & & \\
\hline & Customer compliance & .812 & .563 & & & & \\
\hline \multirow[t]{2}{*}{ Order time } & Order time of customers & .963 & .912 & 2.934 & 71.24 & .915 & .936 \\
\hline & Order time to suppliers & .965 & .913 & & & & \\
\hline \multirow{3}{*}{$\begin{array}{c}\text { Employee } \\
\text { satisfactions }\end{array}$} & Employee's income & .934 & .789 & 2.374 & 73.89 & .915 & .888 \\
\hline & Employee's job satisfaction & .972 & .813 & & & & \\
\hline & Involvement of employees in organization & .997 & .896 & & & & \\
\hline \multirow[t]{4}{*}{$\begin{array}{l}\text { Process } \\
\text { efficiency }\end{array}$} & $\begin{array}{l}\text { Complexity and wordiness of internal } \\
\text { process }\end{array}$ & .697 & .453 & 2.538 & 80.12 & .915 & .753 \\
\hline & Defectives/defects & .918 & .751 & & & & \\
\hline & Waste & .912 & .926 & & & & \\
\hline & Operating costs per unit & .898 & .731 & & & & \\
\hline \multirow{3}{*}{$\begin{array}{c}\text { Process } \\
\text { effectiveness }\end{array}$} & Product/ service quality & .869 & .685 & 2.145 & 85.24 & .915 & .919 \\
\hline & Productivity & .987 & .871 & & & & \\
\hline & Capacity & .934 & .962 & & & & \\
\hline
\end{tabular}

\subsection{Results from Regression Models}

H1: There are positive relationships between "TQM dimensions" and "market and profitability"

$\mathrm{H} 2$ : There are positive relationships between "TQM dimensions" and "customer satisfaction"

H3: There are positive relationships between "TQM dimensions" and "employee satisfaction"

H4: There are positive relationships between "TQM dimensions" and "process efficiency"

H5: There are positive relationships between "TQM dimensions" and "process effectiveness"

H6: There are positive relationships between "TQM dimensions" and "order time"

The six models (TQM-OP1; TQM-OP2; TQM-OP3; TQM-OP4; TQM-OP5; TQM-OP6) are statistically significant at less than 1 percent, and the regression coefficients (beta coefficient) of the significant factors are provided. Since six measures of the organizational performance are found to have significant correlation with the criteria of TQM, the propositions are supported.

In model TQM-OP1 with 'market and profitability' as the dependent variable, process management (TQM5) is significant at $\mathrm{p}<.1$; employee involvement (TQM3) and supplier relationship (TQM7) are significant at $\mathrm{p}<.05$. These items have regression correlations with market and profitability. This partially supported Hypothesis 1 . This implies that the improvement in process management, employee involvement, and supplier relationship will result in better market and profitability of the organizations. The largest impact on market and profitability is supplier relationship 
(beta coefficient $=.341$ ), the next are equal for employee involvement and process management (beta coefficients are .214 and .214 , respectively.

In model TQM-OP2 with 'customer satisfaction' as the dependent variable, employee involvement (TQM3) is significant at $\mathrm{p}<.05$; supplier relationship (TQM7) is significant at $\mathrm{p}<.1$. Two out of the seven QMS criteria have regression correlations with customer satisfaction. This partially supported Hypothesis 2 . Hence, effective employee involvement and supplier relationship will result in increased customer satisfaction. Employee involvement made the highest influence on customer satisfaction (beta coefficient $=.261$ ), followed by supplier relationships (.260).

In model TQM-OP3 with 'employee satisfaction' as the dependent variable, one factor is statistically significant at $\mathrm{p}$ $<.05$, namely, employee involvement (TQM3). Hypothesis 3 is partially supported. When the activities of employee involvement are emphasized, employee satisfaction increases. Employee involvement has beta coefficient of .209.

In model TQM-OP4 with 'process efficiency' as the dependent variable, one factor is statistically significant at $\mathrm{p}<.05$, namely, process management. Hypothesis 4 is partially supported. When the activities of process management are emphasized, process efficiency increases. Process management has beta coefficient of .308 .

In model TQM-OP5 with 'process effectiveness' as the dependent variable, one factor is statistically significant at $\mathrm{p}$ $<.05$, namely, supplier relationship. Hypothesis 5 is partially supported. When the activities of supplier relationship are emphasized, process effectiveness increases. Supplier relationship has beta coefficient of .266.

In model TQM-OP6 with 'order time' as the dependent variable, one factor is statistically significant at $p<.05$, namely, supplier relationship. Hypothesis 6 is partially supported. When the activities of supplier relationship are emphasized, order time increases. Supplier relationship has beta coefficient of .343.

Table 6. Correlation matrix of TQM

\begin{tabular}{|c|c|c|c|c|c|c|c|}
\hline & TQM1 & TQM2 & TQM3 & TQM4 & TQM5 & TQM6 & TQM7 \\
\hline Leadership (TQM1) & 1.00000 & & & & & & \\
\hline Customer focus (TQM2) & $.565 * *$ & 1.00000 & & & & & \\
\hline $\begin{array}{l}\text { Employee involvement } \\
\text { (TQM3) }\end{array}$ & $.443 * *$ & $.457 * *$ & 1.00000 & & & & \\
\hline $\begin{array}{l}\text { Information management } \\
\text { (TQM4) }\end{array}$ & $.547 * *$ & $.476^{* *}$ & $.571 * *$ & $\begin{array}{c}1.0000 \\
0 \\
\end{array}$ & & & \\
\hline Process management (TQM5) & $.487 * *$ & $.346^{* *}$ & $.569 * *$ & $.324 * *$ & 1.00000 & & \\
\hline $\begin{array}{l}\text { Continuous improvement } \\
\text { (TQM6) }\end{array}$ & $.594 * *$ & $.506^{* *}$ & $.550 * *$ & $.680 * *$ & $.514 * *$ & 1.00000 & \\
\hline Supplier relationship (TQM7) & $.434 * *$ & $.368^{* *}$ & $.436^{* *}$ & $.300 * *$ & $.565^{* *}$ & $.545^{* *}$ & 1.00000 \\
\hline
\end{tabular}

Table 7. Correlation matrix of TQM and organizational performance

\begin{tabular}{|c|c|c|c|c|c|c|}
\hline & $\begin{array}{l}\text { Market and } \\
\text { profitability }\end{array}$ & $\begin{array}{c}\text { Customer } \\
\text { satisfaction }\end{array}$ & Order time & $\begin{array}{c}\text { Employee } \\
\text { satisfaction }\end{array}$ & $\begin{array}{l}\text { Process } \\
\text { efficiency }\end{array}$ & $\begin{array}{c}\text { Process } \\
\text { effectiveness }\end{array}$ \\
\hline Leadership (TQM1) & $.239 * *$ & $.171^{* *}$ & .217 & $.167 * *$ & $.189 * *$ & $.230 * *$ \\
\hline Customer focus (TQM2) & $.215^{* *}$ & $.168 * *$ & .140 & $.139 * *$ & $.128 * *$ & $.196 * *$ \\
\hline Employee involvement (TQM3) & $.337 * *$ & $.322 * *$ & .325 & $.235 * *$ & $.263 * *$ & $.265 * *$ \\
\hline Information management (TQM4) & $.113^{* *}$ & $.095^{* *}$ & .163 & $.151^{* *}$ & $.125^{* *}$ & $.199 * *$ \\
\hline Process management (TQM5) & $.375^{* *}$ & $.322 * *$ & .338 & $.294 * *$ & $.300 * *$ & $.211^{* *}$ \\
\hline Continuous improvement (TQM6) & $.168 * *$ & $.138 * *$ & .180 & $.122 * *$ & $.134 * *$ & $.114 * *$ \\
\hline Supplier relationship (TQM7) & $.359 * *$ & $.289 * *$ & .343 & $.232 * *$ & $.291 * *$ & $.278 * *$ \\
\hline
\end{tabular}


Table 8. Multiple regression TQM on organizational performance

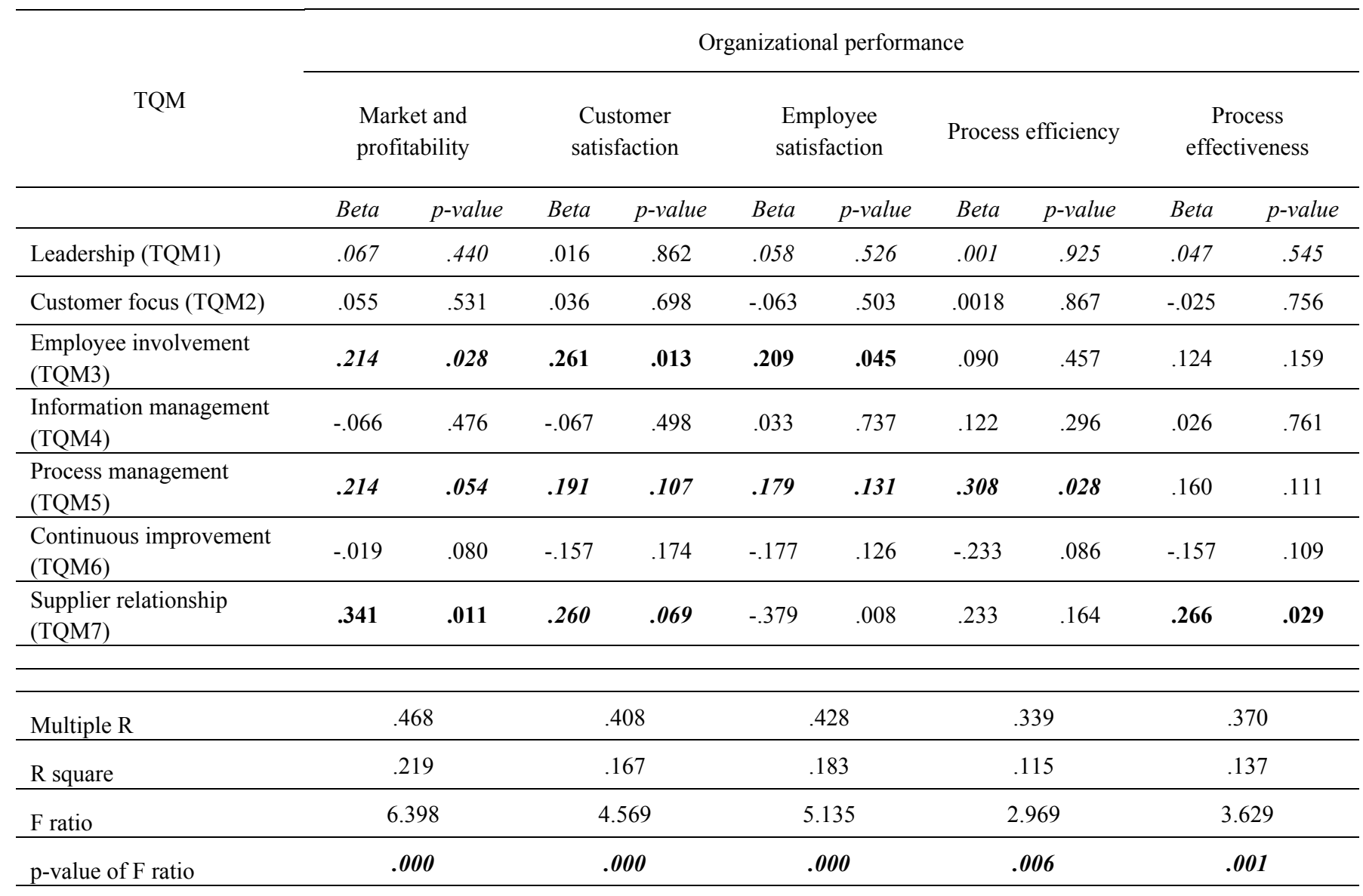

For TQM-OP6 (order time), beta values are $0.094 ; 0.038 ; 0.135 ; 0.126 ; 0.021 ;-0.277$; and $\mathbf{0 . 3 4 3}$, respectively and p-values are $0.252 ; 0.649 ; 0.144 ; 0.153 ; 0.842 ; 0.008 ; \mathbf{0 . 0 0 7}$, respectively. Multiple $\mathrm{R}=0.385 ; \mathrm{R}$ square $=0.148 ; \mathrm{F}$ ratio $=3.973$, p-value $=\mathbf{0 . 0 0 0}$

\section{Conclusions}

Concerning performance improvement of Hanoi construction companies, a conceptual framework was developed in this study. This framework was used not only to evaluate the practices of TQM, but also to examine the relationship between TQM and organizational performance. The measures of TQM were empirically tested to be reliable and valid. The reliability coefficients (Cronbach's alpha) of all measures were above 0.70 . Furthermore, detailed item analysis confirmed that all the items were appropriately assigned to their respective measures. In addition, the extensive literature review and qualitative pre-testing helped to insure that the measures have content validity.

For organizational performance, six factors were extracted from twenty items and used for correlation analysis. They were market and profitability, customer satisfaction, order time, employee satisfaction, process efficiency, and process effectiveness. This study evaluated the impact of TQM dimensions on performance by testing six hypotheses:

H1: There are positive relationships between "TQM dimensions" and "market and profitability"

H2: There are positive relationships between "TQM dimensions" and "customer satisfaction"

H3: There are positive relationships between "TQM dimensions" and "employee satisfaction"

H4: There are positive relationships between "TQM dimensions" and "process efficiency"

H5: There are positive relationships between "TQM dimensions" and "process effectiveness"

H6: There are positive relationships between "TQM dimensions" and "order time" 
Through the multiple regression analysis, the six hypotheses were partially statistically significant. This implies that TQM implementation is really a good way to improve organizational performance.

The results of the six regression models (TQM-OP1; TQM-OP2; TQM-OP3; TQM-OP4; TQM-OP5; TQM-OP6) show that there is enough statistical evidence to demonstrate important relationships between TQM and organizational performance.

Organizations who implement the activities of TQM will positively increase their performance.

In model TQM-OP1, there are three regression relationships with market and profitability, namely, employee involvement, process management, and supplier relationship. The relationship between market and profitability with supplier relationship is explained that organizations focus on developing long term relationships with suppliers, they gain opportunities in occupying and expanding market.

There is one regression relationship with employee involvement in model TQM-OP3. This is employee involvement. In fact, employee involvement impacts on the effort of the employees. When the management emphasizes employee involvement, the employees feel convenient about their job, and they trust the organization. They become actively involved in working and contributing their efforts for the organization. One relationship with process efficiency is shown in model TQM-OP4, namely, process management. When a process becomes efficient, its cost is reduced. This can create more competitiveness for the organization. The relationship of process management to efficiency can be easily interpreted because the objective of process management is to improve sufficiency and effectiveness.

In model TQM-OP5, the only one significant relationship with process effectiveness is supplier relationship. The relationship of supplier relationship with process effectiveness can be explained that focusing on long term relationships with suppliers will result in process effectiveness. By the same token, for model TQM-OP6, the only one significant relationship with order time is supplier relationship. The relationship of supplier relationship with order time can be explained that focusing on long term relationships with suppliers will result in increase in order time.

\section{References}

Adler, N. J. (1983). A typology of management studies involving culture. Journal of International Business Studies, 14(2), 29-48.

Afifi, A. A., \& Clark, V. (1998). Computer aided multivariate analysis. Belmont, CA: Lifetime Learning Publications.

Aka, D. A., Kumar, V., \& Day, G. S. (1998). Marketing research (6 ${ }^{\text {th }}$ ed). New York: John Wiley and Sons

Allen, R. S., \& Kilmann, R. H. (2001). How well does your rewward system support TQM? Quality Pregress, 34(4), 52-57.

Andaleeb, S. S. (1998). Determinants of customer satisfaction with hospitals: A managerial model. International Journal of Health Care Quality Assurance, 11(6), 181-187.

Atchison, T. A. (1996). What is corporate culture? Trustee, 49(1), 28.

Australian Business Excellence Awards (ABA). (2003). Retrieved March 24, 2003, from www.businessexcellenceaustralia,com.au/GROUPS/AWARDS/

Babbie, E. (1990). Survey research methods (2 ${ }^{\text {nd }}$ ed). California: Wadsworth Publishing Company.

Cao, G., Clarke, S., \& Lehaney, B. (2000). A systemic View of organisation change and TQM. The TQM Magazine, 12(3), 186-194.

Carman, J. A., Shortell, S. M., Foster, R. W., Hughes, E.F.X., Boerstler, H., O’Brien, J. L., \& O'Connor, E. F. (1996). Keys for successful implementation of total quality management in hospitals. Health Care Managament Review, 2l(1), 48-60.

Carr, D., \& Littman, I. (1990). Excellence in government: Total Quality Management in the 1990s. New York: Coopers \& Lybrand.

Charmaz, K. (1990). Discovering chronic illness: Using grounded theory. Social Science and Medicine, 30(10), 1161-1172.

Chelly, S. (1996). The case study method for research in small and medium sized firms. International small Business Journal, 15(1), 73-85. 
Chen, F. G. (1999). The impact of the implemantation of total quality management on hospitals' operating performance. Unpublished Msc, Yuan-Ze University, Taiwan.

Cooper, D. R., \& Kaplan, R. S. (1991). Profit priorities from activity-based costing. Harvard Business Review, 69(3), $130-135$.

Cooper, D. R., \& Schindler, P. S. (1998). Business research methods ( $6^{\text {th }}$ ed). Boston : Irwin/McGraw-Hill.

Cowley, S. (1995). Profession development ang change in a learning organization. Journal of Advanced Nursing, 21(5), 965-974.

Creswell, J. W. (1994). Research design: Qualitative \& Quantitative approaches. London: Sage Publications.

Deming, W. E. (1982). Quality, productivity and competitive Position. Cambridge, MA: MIT Centre for Advanced Engineering Study.

Dempsey, C. L. (1995). Nursing home acquired pneumonia: Outcomes from a clinical process improvement program. Pharmacotherapy, 15(1 Pt 2), 33S-38S.

Graxier, K. L. (1999). Collaboration and Quality in managed care. Journal of Healthcare Management, 44(3), 63-165.

Green, S. B. (1991). How many subjects dose its take to do a regression analysis? Multivariate Bahaviour Research, 26, 499-510.

Greene, R., Simmons, J., \& Goden, J. (Ed). (1976). The role of consumer behaviour in the outcome of health services intervention. New York, Ballinger: The State of the Art.

Griffin, R. W. (1993). Management. Boston: Houghton Mifflin Company.

Griffith, J. R. (1994). Reengineering health care: Management systerm for survivors. Hospital \& health Services Administration, 39(4), 451-470.

Grutknecht, D., \& Miller, J. (1990). The organizationL and human resources sourcebook (2 ${ }^{\text {nd }}$ ed). New York: University press og America.

Gull, G. A. (1995). In search of TQM success. Executive Excellence, 12(7), 17-18.

Habib, M., M., \& Victor, B.(1991). Strategy Structure and Performance of U.S manufacturing and service MNCs: A comparative analysis. Strategic management Journal, 12(8), 589-606.

Hackman.J. R., \& Wagemnan, R. (1995). Total quality management: Empirical ,conceptual,and practical issues. Administrative Science Quarterly, 40(2), 309-342.

Haigh, B., \& Morris, D. (1993, September $\left.7^{\text {th }}-10^{\text {th }}\right)$. Quality and productivity in health services through the implementation of total quality management. Proceedings of the European Group of Public Administration, Strasbourg.

Hair, J. F., Anderson, R. E., Tatham, R. L., \& Black, W. C. (1998). Multivariate data analysis (5 ${ }^{\text {th }}$ ed). New Jersey: Prentice hall.

Haker, C. (1996). The corporate sefl-assessment handbook ( $3^{\text {rd }}$ ed). London : Chapman \& Hall.

Kanij, G. K., \& Asher, M. (1993). Total quality management process: a systrmatic approach. Total Quality Management, 4(special issue).

Kaplan, R. S., \& Norton, D. P. (1996). Balanced scorecard: Translating strategy into action. Campridgr, MA: Harvard Business School.

Kazandjian, V. A., \& Lied, T. R. (1998). Cesarean section rates: Effects of participation in a performance measurement project. Joint Commission Journal on Quality Improvement, 24(4), 187-196.

Lai, M. C., \& Tsay, W. D. (2003, April $\left.15^{\text {th }}-20^{\text {th }}\right)$. Total quality management practices and hospitals performanceEvidence in Taiwan. Paper presented at the Thirty Second Annual Meeting of the Western Decision Sciences Institute, Haiwaii.

Langabeer, J. (1998). Competitive stratrgy in turbulent healthcare markets: An Analysis of financially effective teaching hospitals. Journal of Healthcare Management, 43(6), 512-525.

Lawer, E. E., Mohnman, S. A., \& Ledford, G. E. (1995). Creating high performance organizations. San Fansico, CA: Jossey-Bass. 
Meyer, S. M. (1998). Constrasting the original Malcolm Baldridge National Quality Award and the health care pilot award. Quality management in health care, 6(3), 12-21.

Meyer, S. M., \& Collier, D. A .(2001). An empirical test of the causal relationships in the Baldrige Health Care Pilot Criteria. Journal of Operations Management, 19(4), 403-425.

Mintzberg, H. (1991). The effective organisation: Forces and forms. Sloan management Review, 32(2), 54-67.

Morgan, J., \& Everett, T. (1990). Introducing quality managemnent in the NHS. International Journal for Health Care Quality Assurance, 3(5), 23-25.

Moser, C. A., \& Kalton, G. (2001). Survey methods in social investigation $\left(2^{\text {nd }}\right.$ ed). Aldershot, Burlington: Ashgate.

Motwani, J. G. (2001). Measuring critical factors of TQM. Measuring Business Excellence, 5(2), 27-30.

Motwani, J. G., Sower, V. E., \& Brashier, L. W. (1996). Implementing TQM in the health care sector. Health Care Management review, 21(1), 78-82.

Naildu, G. M., Kleimenhagen, A., \& Pillari, G. D. (1992). Organization of marketing in U.S.hospitals: An empirical investigation. Health Care Management Review, 17(4), 29-43.

Nance, J. L. (1995). Managed care: the new paradigm. America On-Line, HMO.

Narver, J. C., \& Slater, S. F. (1990). The effect of a market orientation on business profitability. Journal of Marketing, 54(4), 20-35.

Nohria, N., \& Green, S. (1996). Efficiency and Legitimacy: The adoption of TQM by large corporations. London: Harvard Business SchoolWorking Paper.

Norusis, M. J. (1988). SPSS/Pc+ Studentware. Chicago, IL: SPSS Inc.

Nunnally, J. C. (1978). Psychometric theory (2 ${ }^{\text {nd }}$ ed). New York: McGraw Hill.

Nwabuezw, U., \& Kanji, G. K. (1997). The implementation of total quality management in the NHS: How to avoid failure. Total Quality Management, 8(5), 265-280.

O’Brien, J., Shortell, S. M., Hughes, E. F., Foster, R. W., Carman, J. M., Boerstler, H., \& O’Connor, E. J. (1995). An integrative model for organization -wide quality inprovement: Lessons form the field. Quality management in Health Care, 3(4), 19-30.

Oakland, J. (1993). TQM (2 ${ }^{\text {nd }}$ ed.). Oxford: Heinemann.

Ott, J. S. (1980). The organization culture perspective. Chicago: Dorsey.

Schein, E. H. (1997). Organizational culture and leadership ( $2^{\text {nd }}$ ed). San Francisco: Jossey-Bass.

Scrimshaw, S.C.M., \& Hurtado, E. (1987). Rapid assessment procedures for nutriton and primary health care: Anthropological approaches to improving program effective. Tokyo: United Nations University.

Shart-Hopko, N. C. (2001). Focus group methodology: When and why? The Journal of the Association of Nurses in AIDS Care, 12(4), 89-91.

Shea, J., \& Gobeli, D. (1995). TQM: The experience of ten small businesses. Business Horizons, 38(1), 71-77.

Sheridan, J. E., Fairchild, T. J., Haddock, C., \& Jones, L. (1995). The effectiveness of continuous quality improvement initiatives in nursing facilities. Paper presented at the Academy of Management meeting, Vancourver, B.C.

Sherman, H. A. (1984). Hospital efficiency measurement and evaluation: Empirical test of a new technique. Medical Care, 22(10), 922-938.

Sheu, C., \& Howell, J. (1998). Organization antecedents to the successful implementation of total quality management, Quality Management Journal, 5(3), 3-24.

Shin, D., Kalinowski, J. G., \& EI-Enein, G. A. (1998). Critical implementation issues in Total quality Management Advanced Management Journal, 63(1), 10-14.

Sinclair, D., \& Zairi, M. (1995). Performance measurement as an obstaccle to TQM. The TQM Magazine, 7(2), $42-45$.

Sinclair, D., \& Zairi, M. (1996). Assessing the effectiveness of performance measurement system. Total Quality Management, 7, 367-378. 
Sitkin, S. B., Sutcliffe, K. M., \& Schroeder, R. G. (1994). Distinguishing control from Learning in total quality management: A contingency perspective. The Academy of management Review, 19(3), 537-564.

Smith, H. W. (1991). Strategies of social research $\left(3^{\text {rd }} \mathrm{ed}\right)$. Orlando, FL: Holt, Rinehart and Winston.

Smither, J. W. (1998). Performance appraisal. San Francisco: Jossey- Bass publisher.

Snell, S. A., \& Dean, J. W. (1992). Integrated manufacturing and human resource management: a human capital perspective. Academy of Management Journal, 35(3), 467-504.

Solovy, A. T. (1993). Champions of change. Hospitals, 67(5), 15-23.

Spector, B., \& Beer, M. (1994). Beyond TQM Programes. Journal of Organisation Change Management, 7(2), 63-70.

Spencer, B. (1994). Models of organization ang total quality management: A comparison and critical evaluation. Academy of Management Review, 19(3), 446-472.

Sprent, P. (1998). Understanding data. Penguin: Harmondsworth. 